\title{
Using Language Experience Approach (LEA) and Talk Massage Symbol Visible (TMSV) Method in Learning of Speech Skill of Indonesia Students
}

\author{
Abdul Munir K. \\ Tarman \\ Asriani Nur \\ Muhammad Harun \\ Indonesian Language and Literature Education Department, \\ Muhammadiyah University of Makassar, Indonesia
}

Doi: $10.36941 /$ jesr-2019-0008

\begin{abstract}
The study was described using language experience approach (LEA) and talk massage symbol visible (TMSV) method in learning speech skill. The results of this study used a descriptive quantitative approach. The research was set at Elementary School, Gowa Regency of Indonesia. The data of this study was speech skills include linguistic and non-linguistic factors. The technique used in data collection is, 1) observation, 2) pre-test. Data analysis includes stages: 1) data collection, 2) data reduction, 3) data presentation, and 4) verification and conclusion. The conclusion of the results of the data analyst was as follows: a) Data obtained from the observation of students categorized above the average value of 75 as many as 20 students or $87 \%$, while those who obtain scores below the average of 75 are 3 students or $13 \%$. The results of these data indicated that the ability of students in speaking skill of learning very satisfying, b) Data obtained from inferential statistical test results obtained $t$ count $=22.94$ and $t_{\text {table }}=2.074$ obtained data $t_{\text {count }}>t_{\text {table }}$ or $22.94>2.074$. It concluded that $H_{0}$ rejected and $H_{1}$ accepted. It means that the application of the TMSV method affect in learning of speech skill at Elementary School of Indonesia.
\end{abstract}

Keywords: Language experience, TMSV, method, speaking, learning

\section{Introduction}

In the world of education, human life cannot be separated from language activities. Language is a tool and tool for communicating between students and students, teachers with students and vice versa. Language is a communication tool, in order to fulfill human nature as individual and social beings who need to interact with each other. Language as the most perfect tool and is able to present thoughts and feelings both about things that are concrete and abstract (Effendi, 1985: 5). In line with the development of science and technology education actors are required to have good language skills. Someone who has adequate language skills is easier to absorb and convey information both orally and in writing.

Language skills consist of four aspects, namely listening or listening, speaking, reading, and writing. Students must master the four aspects in order to be skilled in language. Thus, learning speaking skills in schools does not only emphasize theory, but students are required to be able to use language as its function, namely as a tool for communication. The language aspect that must be mastered by students is speaking, because speaking skills support other skills (Tarigan, 1986: 
86). Speaking skills are not a type of skill that can be inherited from generation to generation even though basically every human being can speak. Learning formal speaking skills requires intensive training and direction. Stewart and Kennert Zimmer (Haryadi and Zamzani, 1997: 56) see that effective communication needs are needed as an essential to achieving success for each individual and group. Students who have good speaking skills, the conversation is more easily understood by the listeners. Speaking skills support reading and speaking skills. Speaking skills have similarities, namely as language production activities and conveying information. Students' ability to speak is useful in listening and understanding reading activities. The problem found in the field is that not all students have good speaking skills. Therefore, the development of speaking skills must be done as early as possible.

Supriyadi (2005: 178) stated if a person has good speaking skills, he will gain social and professional benefits. Social benefits are related to community interaction activities with individuals. Whereas, profits in the professional field are obtained when using language to make and provide questions, convey facts and knowledge, explain and describe.

These spoken language skills make it easier for students to communicate and express ideas or ideas to others. The need for mastery of speaking skills for elementary school students, in accordance with the opinion expressed by Farris (in Supriyadi, 2005: 179) that learning important speaking skills is mastered by students in order to be able to develop the ability to think, read, speak, and listen. The ability to think elementary school students will be trained when they can conceptualize, organize, clarify, and simplify thoughts, feelings, and ideas to others verbally.

Based on the context of the use of LEA in speaking learning above, in general, the problem is formulated to be "What is the use of a language experience approach through the TMSV method in formal speaking skills in the context of conceptualizing, organizing, clarifying", and simplifying thoughts, feelings, and ideas to others verbally In detail, the general problem of research: (a) how is the use of the language experience approach through the TMSV method in the context of speaking skills?

This study aims to describe the ability and formal language skills formally through speech learning using the TMSV method, where elementary students are able to formulate ideas, ideas, and scientific or technical arguments responsibly based on educational ethics, and can communicate it through the TMSV method to the wider community. Based on specific goals will contribute to the ethnographic theory of communication, and speaking skills. Contributions to the ethnographic theory of communication can describe oral peculiarities in language. For speaking theory can enrich aspects of language skills. And for the theory of language experience approaches can understand ways or methods in learning speaking skills. In line with the opinion of Harjasujana, (1997: 198) which says that the basic assumption of the use of this LEA is the expression of students' oral language based on their own thoughts, feelings, and experiences that can be written and read. This activity can be equated as students read other people's ideas that have been poured into written form. Further Harjasujana (1997: 198)) says the Language Experience Approach adheres to the view that children will more easily recognize their own writing, because the words contained in the writing are reflections or reflections of their daily lives. The language used is a language that is familiar with life, namely a language that describes the background of his personal experience.

The Language Experience Approach is an approach that can be used for speaking teaching followed by other language skills, namely listening, speaking, reading and writing. Children's oral language is the main foundation in managing speaking learning. This language experience approach strongly emphasizes the importance of the learner's initial conditions in terms of oral language skills. Thus, the implementation of speaking learning is always preceded by the exploration of children's language experiences which are expressed verbally, then recorded into written form and in the form of stories. These recordings are then used as tools for learning to speak. In other words, the Language Experience approach adheres to the learning view of children, for children, and by children. The hope of learning with an approach like this is that learners are more successful when the learner believes he is capable and able to do something from the beginning. With teaching materials extracted from the students themselves, students are expected to more easily understand the contents of the material in learning. In this way students have 
confidence and state that everything they learn is something meaningful (has use value).

Based on the LEA theory and functional language theories proposed by some previous experts, the research team agreed to give birth to a method named the TMSV method. The TMSV method stands for: Told (tell or say), Message (message), which is implied in Syimbol (symbol or sign), which is Visible (visible or visible), amk (abbreviation of abdul munir kondongan). So, the meaning of the term TMSV is to say or tell the message that is in a visible or visible symbol (Munir. Abdul et al: June 2019). This method is based on student experience that is contextual in nature. The TMSV method is inspired by the language experience approach (PPB) which is the transfer of words from Language Experience Approach (LEA). The TMSV method is closely related to Contextual Learning. CTL (Contextual Teaching and Learning) is a holistic learning process and aims to motivate students to understand the meaning of the subject matter they are learning by linking material to the context of their daily lives (both personal, social, and cultural contexts) so that students have knowledge and skills which can be flexibly applied (transferred) from one problem I context to another problem / context.

The Language Experience Approach is a word transfer from the term Language Experience Approach (LEA). As quoted by Harjasujana (1997: 196-197) that Huff defines LEAs are based on meanings contained in the elements of their forming words, especially the words experience and language. According to Huff, experience is a person experience obtained from certain activities. Meanwhile, language reflection includes listening, speaking, reading and writing. LEAs are interpreted as an approach to teaching speaking that involves listening, reading and writing a reflection of the children's language experience. According to Harjasujana (1997: 197), the things that must be considered in the Language Experiences Approach (PPB) are: 1) PPB is a teaching approach. The implementation of learning involves all aspects of students' language skills integrative. Advantages of the Language Experiences Approach

The advantages of the Language Experiences Approach are as follows: 1) the nature of the Language Experience Approach begins with the question of children's language development. That is, the material of teaching materials used for teaching speaks according to the level of mastery of the child's language. The task of choosing suitable materials is light because the discourse used is in accordance with the level of mastery of the child's language, 2) The nature of the Language Experiences Approach integrates all linguistic activities. In the implementation of the learning process, children listen, speak, read, and write, sometimes also discussing the discourse that is being developed, 3) The Language Experiences Approach has a reasonable nature, 4) The Language Experiences Approach does not require a lot of costs.

\subsection{Weaknesses of the Language Experiences Approach}

The weaknesses of the PPB are as follows: 1) the nature of the Language Experiences Approach is only used in the teaching of mastering language skills at the primary and secondary levels of elementary school. Furthermore, the Language Experience Approach can be developed in teaching mastery of language skills, namely listening, speaking, reading, and writing for the advanced level. This can be developed because there are children who sit in the upper class, but the mastery ability of language skills is still at the beginning of the rank, 2) MARPs require far more time than the other approaches, 3) MARPs require students to always be aware of a number of skills and a number of vocabulary so the teacher must know what is taught and when to teach it.

\subsection{Understanding of Speeches}

Speeches are generally shown to people or groups of people to express their congratulations, welcome guests, commemorate holidays, but sometimes speech is the delivery and planting of thoughts, information, or ideas from the speaker to many people (Karomani, 2011: 12). In addition, another opinion states that speech is a way of expressing thoughts that are expressed in the form of words to many people. People who can speak well mean that they can express their thoughts well (Adhitya, 2010: 1). A person who speaks well will convince his audience to accept and obey thoughts, information, ideas or messages conveyed (Maidar, 1991: 55). In addition to Maidar, 
according to the General Dictionary of Indonesian Language (1990: 766) speech is the expression of thoughts in the form of words shown to many people. Based on some of the opinions above, the author refers to the opinion of Adhitya (2010: 1) arguing that speech is a way of expressing thoughts that are expressed in the form of words to many people. People who can speak well mean that they can express their thoughts well.

\subsection{Speech Learning}

Speech is an activity of speaking in front of the public, in class or speech in expressing his opinion, or giving a picture of something. Usually a speech is delivered by a person / student who gives speeches and statements about important things or events and should also be discussed. Speech is usually used by one / student to lead and give speeches in front of a general / sailor or general audience. Speech is a speech that has a good arrangement to be conveyed to the audience. The ability to speak or speak in public can help in achieving a good career path. Speech is one form of oral language activities. Therefore, the speech emphasizes the expression of ideas and reasoning by using spoken language supported by non-language aspects, such as facial expressions, pronunciation, contact point of view, and voice intonation. A good speech requires several criteria. The following are the criteria in the speech as follows: 1) The content of the speech to be delivered has conformity with the activities or events that take place, 2) The contents are evocative and can be useful for the audience of the speech, 3) The contents of the speech do not cause conflict, 4) The contents are correct, objective, and clear, 5) The language used can be easily understood by listeners, 6) The language is delivered politely, friendly, and humble.

The speech method refers to the steps and the sequence from which to start the speech, develop, and end the speech. The ethics of giving a speech refers more to propriety values that must be considered and respected when someone is giving a speech. The order in the speech usually begins with the opening, the presentation of the contents of the speech, and the closing. The presentation of the contents of the speech is the result of the elaboration of the ideas of the points that will be delivered at the time of the speech. The content needs to be specified in accordance with the conditions provided. The closing of the speech was about refresher from the main ideas that had been conveyed, expectations, and thanks to the listeners for their participation. The speech ethics is an important grip for the person who will speak. When giving a speech, you should not offend others and try to respect and build a sense of optimism for the audience. In addition, attention is also given to openness, honesty, empathy, and friendship that need to be sought in speeches.

\subsection{Speech Steps}

In order for speech activities to run well, there are several steps that must be prepared by students. Following are the steps to give a speech according to some expert opinions. Regular preparation and training are needed so that speech activities can take place well. For some people who are already accustomed to giving speeches to the masses, speech preparation and training may not be needed anymore. However, for people who have never had a speech this is very necessary. Anwar (1995: 36) suggests that there are three steps to speech preparation, namely (a) physical preparation, (b) mental preparation, and (c) preparation of material that can support the success of one's speech. The description is as follows.

1. Physical Preparation: Physical preparation that needs to be done by students in a speech is to maintain the health of the body so that it is always in top condition. This body health is very influential on the personal appearance of students when giving speeches and can affect the health of one's mind. If the body is healthy, the contents of the mind will come out systematically and regularly. Physical preparation will also support other factors, such as eyesight, facial expressions, sounds, and hand movements.

2. Mental preparation: Mental preparation that needs to be done by students in speech activities is that students must make efforts that can lead to courage and confidence so that the student is able to give a speech in front of friends in front of the class. Mental 
preparation is needed by students to avoid undesirable things. For example, stage fever, pallor, loss of material, and loss of voice.

3. Material preparation: Material preparation needs to be done by students. The preparation is to make efforts to master the material that will be delivered in front of his friends. Preparation can be done by starting to prepare the topic of speech, looking for materials that support, make a framework, and record important things to be conveyed. With the three preparations students can speak well.

Speech According to Keraf; There are seven stages that need to be considered in good speech preparation, namely (a) determining the topic and purpose, (b) analyzing the situation and the listener, (c) selecting and narrowing the topic, (d) collecting materials, (e) creating a description frame, (f) describe in detail, (g) train with a loud voice (Keraf, 1994: 317). The details as follows:

a. Determine Topics and Objectives; The first step that must be considered in preparing for a speech is to determine the topic and purpose. The subject or topic of conversation is a problem raised, while the purpose of the conversation relates to the expected response of the listener regarding the issue raised.

b. Analyzing Situations and Listeners; analyzing the situation and the listener first needs to be done so that the conversation can reach its goal. The things that must be considered in analyzing the listener are (1) the listener's knowledge of the topic being delivered, (2) the interest and desires of the listener, (3) the attitude of the listener, while in analyzing the situation things must be considered (1) the purpose of listening, (2) customs or procedures for the life of the listener, (3) the arrangement of the program, (4) the place where the conversation takes place.

c. Select and Narrow Topics; Selection of topics should be adjusted to the nature of the meeting as well as data and information about the situation and listeners who will attend the meeting. Issues or topics that will be presented are not too broad, but must be narrowed or limited, according to the time available.

d. Collecting Materials; before compiling a speech text, the speaker must first collect the necessary material. The material must be related to the issue or topic being discussed. More complete material obtained, will facilitate the speaker in compiling a speech text. The material obtained will complement the speaker's knowledge and experience in processing a speech delivered.

e. Creating a Description Framework; In outlining the problem or topic to be discussed, it is divided into sections or subtopics. Each section is divided into smaller parts and explains the previous section.

f. Describing in detail; Description or manuscript is prepared based on the framework that has been made before. With a detailed and well-structured framework, the drafting of the manuscript is expected to not experience significant difficulties.

g. Train with Sound Loudness; before delivering something in public, the speaker should first do the exercises to read the speech so that in time he can do the speech smoothly.

\subsection{Purpose of Speech}

Speech activities, of course there are intentions and objectives of the message that the speaker will deliver to the listener. The following is a breakdown of several objectives in the speech presented by Keraf in Kundharu and Slamet (2014: 58). a) Encourage the speaker to encourage, arouse enthusiasm, and show respect, and dedication, b) Convincing, the speaker tries to influence the mental / intellectual beliefs or attitudes of the listener, c) Acting / acting, the speaker wants actions or physical reactions from listener with the arousal of emotion, d) Notify, the speaker tries to describe or convey something to the listener, with the hope that the listener knows about something, knowledge, etc. e) Pleasant, the speaker intends to delight, entertain the listeners to escape the wrinkles experienced by listener. 


\section{Research Methods}

\subsection{Types of research}

This research is applied research which combines quantitative description research and qualitative description research. Quantitative research adheres to the perspective of positivism, namely the perspective that says that the existence of social and physical reality is something that is independent or separate, free or outside of the researcher. Therefore anyone who will examine the reality can observe or measure it. The purpose of this applied research is to describe and explain the relationships between measured variables. Furthermore, the focus on reality reduction becomes a variable that can be measured by an instrument that produces numerical data and is in the form of distribution. Related to this applied research, the researchers chose the field experiment research method, namely school. (H.Djaali: 2012). Qualitative description research is based on the assumption that reality is subjective and plural as existing in the individual participants studied (ontological assumptions) in (H.Djaali: 2012). The researcher tried to approach the participants in data collection (systemic assumptions), and using narrative styles, using qualitative terms. Limits or definitions used as rhetorical assumptions, inductive logic, work in detail, and detailed descriptions of contexts. In short, researchers use naturalistic qualitative research and qualitative research that are descriptive analytical on data presented in the form of words.

\subsection{Research sites}

The research location was in elementary school, Gowa Regency of Indeonesia. The location is an elementary representation that uses a language experience approach (LEA) in learning.

\subsection{Population and Samples}

This research data in the form of the use of language experience approach in learning speaking skills include linguistic and non-language data. The source of the research data was the sixth grade students of the Elementary School in with a population of 23 students.

\subsection{Data collection technique}

The techniques used in data collection are (1) observation, (2) Pretest and Posttest, and (3) interviews. The observation technique used in this study, namely non participatory observation techniques, namely researchers are limited to recording events or things related to the setting and atmosphere of emergence of linguistic and non-language factors needed on the field note sheet, as well as recording the interaction of the speaker with audience (recipient / listener) that happens in class. The test technique was conducted to determine the high and low learning outcomes of speaking skills the interview technique is used to obtain data that is not recorded with HP and which is not observed or not recorded in the field notes when carrying out observations. The interview results were used as supporters of observation data in interpreting students.

\subsection{Research Instrument}

Ethnographic qualitative research places researchers as key instruments. For this reason, in conducting this research, researchers hold a key role, both in the process of collecting, analyzing, and summarizing the research findings. In its implementation, researchers use supporting instruments, namely (1) data classification guide format, (2) field note guidance format consisting of (a) descriptive field notes and (b) reflective field notes, (3) interview guide format, (4) data analysis guide format, and (5) HP for recording conversations related to linguistic and non-linguistic factors in the background of students' personal experiences naturally and the necessary writing instruments. 


\subsection{Data analysis technique}

Data analysis in this study uses an interactive model which includes stages: (1) data collection (2) data reduction, (3) data presentation, and (4) verification and conclusion. The four stages of data analysis have varied characters and activities. However, the four stages of data analysis have a link between the processes with each other. First, the data obtained is classified by selecting and determining which data is needed and data that is not needed in response to research problems. Second, arrangements and storage are carried out. Third, the data are analyzed categorically which includes identification, classification, and storage of data relating to the manifestation of the use of the language experience approach to be interpreted ethnographically by the communication of the Hymes model (1962: 26; 1972: 58). With regard to the process of collecting data, analysis is carried out in the field. The analysis is preliminary then followed by further analysis. The results of the analysis and preliminary interpretation of the form of use of the language experience approach (LEA), are recorded in the field notes and verified to obtain a reference frame for subsequent data collection. Such things are done repeatedly and so on until all data is collected and stated enough then the reduction and presentation of data is carried out and the overall conclusion is made.

\section{Results and Discussion}

Based on the results of the research that has been analyzed, this section described the discussion of the results of the research analysts which includes the discussion of the results of descriptive and inferential analysis.

\subsection{Results and Discussion of Descriptive Analysis}

1. Student learning outcomes before applying the TMSV method: The results of data analysis, student learning outcomes before applied speech learning using the TMSV method showed that there were 21 out of a total of 23 students who did not achieve completeness, in other words the student learning outcomes before applying the TMSV method were low and did not meet the classical completeness criteria.

2. Student learning outcomes after the TMSV method is applied: The results of the analysis of data and student learning outcomes after applied speaking skills using the TMSV method showed that there were 23 students who achieved individual completeness (minimum score of 70 ) and no students did not achieve mastery

3. Improving student learning outcomes after learning: The results of data analysis from student learning outcomes after the application of Indonesian language learning through the TMSV method showed that the average score of students after being applied to the TMSV method (Posttest) experienced a significant or higher increase of 82.60 with a score of 30 compared to the pretest or before the treatment was carried out, it was 37.82 with a score range of 50 . Thus according to the effectiveness criteria, student learning outcomes increased after being treated using the TMSV method.

\subsection{The Results and Discussion of inferential statistical analysis}

In the paired test the $T$ Test used a significance level of $5 \%$ or 0.05 . Then get $t_{\text {count }} 22.94$. To find $t_{\text {table }}$ the researcher used a distribution T table with a significant level $\alpha=0.05$ and $d b=\mathrm{N}-1=23$ $1=22$, then it gets $t 0.05=2.074$. After obtaining $t_{\text {count }}=22.94$ and $t_{\text {table }}=2.074$, it is obtained $t_{\text {count }}$ $>t_{\text {table }}$ or 22.94 $>2.074$. So that it can be concluded that Ho is rejected and H_1 is accepted. This means that the application of the TMSV method affects the speech skill of elementary students, Gowa Regency.

\section{Conclusion}

There was a significant or higher increase of 82.60 with a score range of 30 compared to the 
pretest or before the treatment was carried out in 37.82 with a range of scores of 50 . Thus according to the effectiveness criteria, student learning outcomes increased after being treated using the TMSV method.

The conclusion is according to the results of the T Test that $\mathrm{H}_{\mathrm{o}}$ is rejected and $\mathrm{H}_{1}$ is accepted. This means that the application of the TMSV method affects the speech skills of elementary students, Gowa Regency.

\section{References}

Arikanto, Suharsimi. 2006. Penelitian Tindakan kelas. Jakarta: BumiAksara.

Arsad, Maidar G. Dan U. S. Mukti. 1988. Pembinaan Kemampuan Berbicara Bahasa Indonesia. IKIP Jakarta: Erlangga.

Alwi, Hasan, dkk. 2000. Tata Bahasa Baku Bahasa Indonesia. Jakarta: Balai Pustaka

Akhmad Sudrajat. 1986. Pengertian Pendekatan, Strategi,Metode, Teknik dan Model Pembelajaran. Bandung: Sinar Baru Algensindo

Anwar, Gertari. 1995. Teknik dan Seni Berpidato. Jakarta: Rineka Cipta

Burhan Nurgiyantoro.1995. Penilaian dalam Pengajaran Bahasa dan Sastra Indonesia. Yogyakarta: BPFE.

Budi, Santoso K. 1990. Problematika Bahasa Indonesia. Jakarta: Reneka Cipta Cox, Carole.1998. Teaching language arts (a student-and response-centered classroom).New York: A Viacom Company.

Depdiknas. 2003. Kurikulum Berbasis Kompetensi Mata Pelajaran Bahasa dan Sastra Indonesia SMA. Jakarta: Depdiknas.

Depdikbud Dirjen Dikti bagian Proyek Pengembangan Pendidikan Guru Sekolah Dasar.

Elyana, Oktariza S. 2011. Kemampuan Berbicara dalam diskusi Kelompok Murid Kelas V SD Ismaria AlQuraniam Raja Basa Bandar Lampung Tahun Pelajaran 2010/ 2011. Skripsi Mahamurid FKIP Unila. Bandar Lampung: FKIP Unila.

Hamalik, Oemar. 2013. Kurikulum dan Pembelajaran. Jakarta: Bumi Aksara

Haryadi. 1997. Berbicara (Suatu Pengantar) Diktat Perkuliahan: IKIP Yogyakarta.

Haryadi dan Zamzani.1996/1997. Peningkatan Keterampilan Berbahasa Indonesia.

Keraf, Gorys. 1994. Komposisi. Jakarta: Nusa Indah

Karomani. 2011. Keterampilan Berbicara 2. Ciptaan Tanggerang Selatan:Matabaca Publishing.

Kundharu S dan St. Y. Slamet. 2004. Pembelajaran Keterampilan Berbahasa Indonesia. Yogyakarta: Graha IImu.

Mulyasa, E. 2009. Kurikulum Tingkat Satuan Pendidikan. Bandung: PT. Remaja Rosda Karya.

Muchlisoh, dkk.1996. Pendidikan Bahasa Indonesia 3 Modul 1-9. Jakarta:Depdikbud.

Nababan, P.W.J. 1986. Sosiolinguistik suatu pengantar. Jakarta: Grametode Pustaka Umum.

Nurgiantoro, Burhan. 2001. Penelitian dalam Pengajaran Bahasa dan Sastra Indonesia BPFE. Yogyakarta

Purwadarminta, W. J. S. 1990. Kamus Besar Bahasa Indonesia. Jakarta:Balai Pustaka.

Rachmat, Jalaludin. 2001. Retorika Modern Pendekatan Praktis. Bandung: PT Remaja Rosdakarya.

Semi, M. Natar. 1991. Terampil Berpidato. Bandung: Titian Ilmu.

Supriyadi, dkk. 2005. Pendidikan Bahasa Indonesia 2. Jakarta: Depdikbud.

Tarigan, H.G. 1986. Berbicara sebagai suatu Keterampilan Berbahasa. Bandung: Angkasa. Badudu (1993:131)

Tarigan, Djago.1997. Pengembangan Keterampilan Berbicara. Jakarta:Depdikbud.

Tompkins, Gail E \& Hosskisson.1993. Language arts: content and teaching strategies. New York: Macmillan College Publishing Company.

Tarigan, Henry Guntur. 1987. Berbicara Sebagai Suatu Keterampilan Berbahasa. Bandung: Angkasa

Warsita, Bambang. 2008. Teknologi Pembelajaran, Landasan dan Aplikasinya, Jakarta: Rineka 